Article

\title{
The Protective Effect of Static Magnetic Fields with Different Magnetic Inductions against Fluoride Toxicity Is Related to the NRF2 Signaling Pathway
}

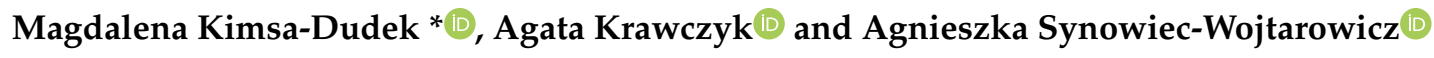 \\ Department of Nutrigenomics and Bromatology, Faculty of Pharmaceutical Sciences in Sosnowiec, \\ Medical University of Silesia, Katowice, Jednosci 8, 41-200 Sosnowiec, Poland; akrawczyk@sum.edu.pl (A.K.); \\ asynowiec@sum.edu.pl (A.S.-W.) \\ * Correspondence: mkimsa@sum.edu.pl; Tel.: +48-32-364-11-72
}

Received: 14 August 2020; Accepted: 16 September 2020; Published: 18 September 2020

check for updates

\begin{abstract}
A redox imbalance disrupts the cellcycle and the proliferation process, and contributes to the initiation of programmed cell death. One of the pathways that are important for redox homeostasis is the Nrf2-ARE signaling pathway. Fluoride as well as static magnetic fields (SMF) are associated with the concepts of oxidative stress, and thus programmed cell death. Therefore, this study aimed to assess the connection between oxidative stress and apoptosis in human cells co-exposed to fluoride and a SMF with a different magnetic induction and to determine whether the Nrf2-signaling pathway is involved in these effects. The research was realized using normal human dermal fibroblasts that had been co-exposed to fluoride $(0.3 \mathrm{mmol} / \mathrm{L})$ and a SMF with a different magnetic induction $(0.45 \mathrm{~T}, 0.55 \mathrm{~T}, 0.65 \mathrm{~T})$ for $12 \mathrm{~h}$. The mRNA levels of the cellular antioxidant system-related genes and apoptosis-related genes were assessed using the quantitative reverse transcription polymerase chain reaction (RT-qPCR) method. Our results indicated that the increased activity of antioxidant enzymes (SOD1 (superoxide dismutase 1), SOD2 and GSR (glutathione reductase)) suggests the restoration of the cell redox homeostasis that had been disturbed by fluoride, and also that the genes whose expression is associated with the induction of apoptosis are down regulated as a result of exposure to a SMF. The SMF with a $0.65 \mathrm{~T}$ flux density had the strongest effect on the fibroblasts. Moreover, our findings demonstrated that the Nrf2 transcription factor plays a crucial role in the protective effect of a SMF against fluoride toxicity in human cells. The results of these studies can form the basis for developing therapeutic strategies for apoptosis and oxidative stress-related diseases.
\end{abstract}

Keywords: fluoride; static magnetic field; oxidative damage; NRF2-signaling pathway; apoptosis

\section{Introduction}

Fluoride toxicity is linked with, among others, the induction of oxidative stress. A redox imbalance disrupts the cell cycle, the proliferation process and contributes to the induction of programmed cell death $[1,2]$. Moreover, changes at the cellular as well as molecular levels lead to the development of many diseases such as cancer, neurodegenerative diseases or cardiovascular diseases [3-5].

Static magnetic fields (SMF) are ubiquitous in everyday life. Magnetic fields are widespread in the natural environment, and their effect on living organisms has been the subject of many investigations. The presence of magnetic fields in everyday life leads to the hazard of functional disturbances in cells, tissues and biological systems [6]. The results of research to date have not given an unequivocal answer about the beneficial and/or adverse impact of a SMF on the human body. However, it is known that, by affecting the cell membranes, it can alter the intracellular signaling, which can then stimulate the transcription and translation processes, which has implications for numerous cellular processes $[7,8]$. 
Despite the fact that the mechanisms of SMF are not fully understood and although research is still ongoing, there have been reports of the possibility of reducing oxidative stress due to the effects of SMF. Coballase-Urrutia et al. [9] detected a decrease in the levels of malondialdehyde (MDA), nitric oxide (NO) and the glycation end products (AGEs) after exposure to SMF for five days in an animal model. In addition, in a study of men, Sirmatel et al. [10] found a decrease in the oxidative stress index (OSI) and total oxidant status (TOS) after exposure to a SMF. A similar SMF effect was also observed at the cellular level [11,12].

One of the pathways that are important for redox homeostasis is the Nrf2-ARE signaling pathway (NRF2/NFE2L2-nuclear factor, erythroid 2 like 2; ARE—antioxidant responsive element) [13], which is activated by oxidation reactions. A further mechanism of action is the induction of target genes (Nrf2 binds to an ARE). The expression of these genes creates resistance to oxidative stress [14,15]. This is related to the protection of cellular homeostasis and detoxifying genes. This is especially important in the course of inflammation, stress or carcinogenic processes [16]. Due to its mechanism of action, the Nrf2 transcription factor has been used as a modulator in diseases related to oxidative stress. In their study, Sun et al. [17] observed an induction of the NRF2 pathway as a result of exposure to perfluorooctanesulfonate (PFOS) along with an improvement as a result of treatment with the reactive oxygen species (ROS) scavenger N-acetyl-1 cysteine (NAC). However, in the study of Zhang et al. [18], a significant decrease in the level of the antioxidant enzymes and an increase in ROS as a result of the down-regulation of si-NRF2 in pregnant women was observed relative to the control group. In addition, the Nrf2 transcription factor has been used as a marker of the effectiveness of the insoluble-bound polyphenols of the adlay seed in inhibiting oxidative stress in Hep G2 cells [14].

In summary, both fluoride and SMF are associated with oxidative stress, and thus programmed cell death. In addition, there is an environmental and occupational exposure to both factors. Therefore, it is important to learn about the possible effects of exposure to them in order to protect workers. Therefore, the aim of our study was to assess the relationship between oxidative stress and apoptosis in cells that had been simultaneously exposed to fluoride and a SMF with a different magnetic induction and to determine whether the Nrf2-signaling pathway is involved in these effects.

\section{Materials and Methods}

The research was realized using normal human dermal fibroblasts (the NHDF cell line) that had been co-exposed to fluoride and then to SMFs with different magnetic inductions.

\subsection{Cell Culture}

The NHDF cell line was purchased from Clonetics (CC-2511, San Diego, CA, USA) and was cultured as was previously described [11].

For the experiment, the fibroblasts were plated at $5 \times 10^{5}$ cells in $25 \mathrm{~cm}^{2}$ culture vessels (Sarstedt, Nümbrecht, Germany) and pre-incubated for $24 \mathrm{~h}$ in an atmosphere of $5 \% \mathrm{CO}_{2}$ at $37^{\circ} \mathrm{C}$. Then, the cells were treated with sodium fluoride $(\mathrm{NaF})$ at a concentration of $0.3 \mathrm{mmol} / \mathrm{L}$ and were exposed to a moderate-strength SMF with different magnetic inductions $(0.45 \mathrm{~T} ; 0.55 \mathrm{~T}$ and $0.65 \mathrm{~T})$ for $12 \mathrm{~h}$. The NaF was dissolved in phosphate-buffered saline (PBS, Lonza, Basel, Switzerland), and a dilution was prepared in the culture medium. The concentration of fluoride was selected on the basis of previous research [11]. The SMF was generated using permanent magnets in patented magnetic chambers that were designed to test the impact of SMF in vitro (patent P-396639). The research was conducted with magnetic field intensities that were parametrically changed by altering the distance from the permanent magnets. In addition, a control was used in which steel was employed instead of a magnet $(0.0 \mathrm{~T})[11,12,19,20]$. A Gauss meter was used to assess the flux densities. SMF in the range of a moderate magnetic induction do not exhibit cytotoxic properties [21].

The cells were then washed with PBS and collected for storage at $-70{ }^{\circ} \mathrm{C}$ for RNA extraction. 


\subsection{RNA Extraction}

Total RNA was isolated using a TRIzol reagent (Invitrogen, Carlsbad, CA, USA) according to the manufacturer's protocol. Qualitative and quantitative evaluations of the extracts were carried out as was previously described [11].

\subsection{Quantitative Reverse Transcription Polymerase Chain Reaction (RT-qPCR) Assay}

The mRNA levels of the cellular antioxidant system-related genes (SOD1—superoxide dismutase 1, SOD2—superoxide dismutase 2, GSR — glutathione reductase, CAT—catalase, GPx1—glutathione peroxidase 1, MGST1-microsomal glutathione S-transferase 1 and NFE2L2-nuclear factor erythroid 2-related factor 2) and apoptosis-related genes (BAX-BCL2 associated X, apoptosis regulator, $B C L 2$ - B-cell lymphoma 2, $B C L X L-B$-cell lymphoma-extra large, $C A S P 2$ - caspase 2, CASP3-caspase 3, CASP9—caspase 9, FAS-Fas cell surface death receptor, FASL-Fas ligand, TNF-tumor necrosis factor and TNFR1-tumor necrosis factor receptor 1) were assessed using the quantitative reverse transcription polymerase chain reaction (RT-qPCR) technique using SYBR Green I chemistry (SYBR Green QuantiTect RT-PCR Kit; QIAGEN, Valencia, CA, USA) and an Opticon ${ }^{\mathrm{TM}}$ DNA Engine Continuous Fluorescence Detector (MJ Research, Watertown, MA, USA). All of the samples were tested in triplicate. In addition, $\beta$-actin was the endogenous control and wells without the RNA template were the negative control. The oligonucleotide primers and the RT-qPCR thermal profile were previously reported by Pawłowska-Góral et al. [22] and Kimsa-Dudek et al. [23]. The results were performed as the copy number mRNA/ $\mu \mathrm{g}$ RNA.

\subsection{Apoptosis Assay}

Apoptosis was assessed using a BD FACS Aria II flow cytometer and a Vybrant Dye Cycle Violet/SYTOX AADvanced Apoptosis Kit (Thermo Fisher Scientific, Waltham, MA, USA) according to the manufacturer's protocol as was previously reported [23].

\subsection{Statistical Analyses}

The results were analysed using Statistica 13.1 software (StatSoft, Kraków, Poland) using one-way analysis of variance (ANOVA) and Tukey's post hoc tests. The values were expressed as the means and standard deviation (SD). The Pearson's correlation coefficient was used to evaluate the relationship between the cellular antioxidant system and apoptosis process. In addition, the interactions between the proteins that are encoded by the analysed genes were examined using the STRING database (Search Tool for Retrieval of Interacting Genes/Proteins) (version 11.0). The results were considered to be statistically significant when the significance level was $p<0.05$.

\section{Results}

\subsection{Transcriptional Activity of the Cellular Antioxidant System-Related Genes}

RT-qPCR analysis showed statistically significant changes in the expression of the cellular antioxidant system-related genes such as SOD1, SOD2, GSR and NFE2L2 among the tested cell groups (Table 1). The mRNA level of SOD1 was significantly higher in the cells that had been co-exposed to fluoride and the SMF with a $0.65 \mathrm{~T}$ flux density compared to the cells that had been co-exposed to fluoride and the SMF with a $0.45 \mathrm{~T}$ (Tukey's post hoc test, $p=0.026$ ) or with a $0.55 \mathrm{~T}$ (Tukey's post hoc test, $p=0.005$ ) flux density. In the case of the SOD2 gene, there was statistically significant increase in its expression in the NaF-treated fibroblasts and simultaneously exposed to the SMF with a $0.65 \mathrm{~T}$ flux density compared to the control cells (Tukey's post hoc test, $p=0.008$ ) and those that had only been treated with fluoride (Tukey's post hoc test, $p=0.022$ ). Moreover, the transcriptional activity of glutathione reductase increased significantly in the NaF-treated cells and simultaneously exposed to the SMF with a $0.65 \mathrm{~T}$ flux density compared to the control cells (Tukey's post hoc test, $p=0.002$ ), 
the cells that had only been treated with fluoride (Tukey's post hoc test, $p=0.005$ ) and the cells that had simultaneously been exposed to fluoride and the SMF with a $0.45 \mathrm{~T}$ flux density (Tukey's post hoc test, $p=0.001$ ). In turn, the level of the NFE2L2 expression decreased statistically significant due to the action of fluoride. We did not detect statistically significant changes in the gene expression of $C A T$, GPX1 or MGST1 under the influence of fluoride and a SMF.

Table 1. The expression of the cellular antioxidant system-related genes in fluoride-treated fibroblasts and in fibroblasts that had been treated with fluoride, and then subjected to the influence of static magnetic fields (SMFs) of different intensities $(0.45,0.55$, and $0.65 \mathrm{~T})$ for $12 \mathrm{~h}$ compared to the control culture without fluoride and without the magnet (flux density $0.0 \mathrm{~T}$ ).

\begin{tabular}{|c|c|c|c|c|c|c|}
\hline & C & F & F + SMF1 & F + SMF2 & F + SMF3 & ${ }^{*} p$ \\
\hline \multicolumn{7}{|c|}{ mRNA Copy Numbers/ug RNA } \\
\hline $\begin{array}{c}\text { SOD1 } \\
\text { (superoxide dismutase 1) }\end{array}$ & $1,359,583 \pm 114,105$ & $1,438,688 \pm 177,946$ & $1,343,500 \pm 19,0836$ & $1,239,125 \pm 163,142$ & $1,764,375 \pm 183,910$ & 0.007 \\
\hline $\begin{array}{c}\text { SOD2 } \\
\text { (superoxide dismutase 2) }\end{array}$ & $200,606 \pm 21,341$ & $206,831 \pm 15,712$ & $228,050 \pm 13,736$ & $216,919 \pm 13,361$ & $251,125 \pm 22,574$ & 0.009 \\
\hline $\begin{array}{c}\text { GSR } \\
\text { (glutathione reductase) }\end{array}$ & $65,088 \pm 4503$ & $69,269 \pm 11,353$ & $63,300 \pm 16,230$ & $80,150 \pm 4503$ & $101,813 \pm 11,462$ & $<0.001$ \\
\hline $\begin{array}{c}C A T \\
\text { (catalase) }\end{array}$ & $47,069 \pm 15,632$ & $51,825 \pm 9008$ & $58,769 \pm 8490$ & $61,044 \pm 16,132$ & $60,588 \pm 10,691$ & NS \\
\hline $\begin{array}{c}\text { GPx1 } \\
\text { (glutathione peroxidase 1) }\end{array}$ & $544,500 \pm 81,698$ & $511,500 \pm 48,140$ & $522,750 \pm 63,346$ & $507,000 \pm 30,043$ & $473,500 \pm 65,479$ & NS \\
\hline $\begin{array}{c}\text { MGST1 } \\
\text { (microsomal glutathione } \\
\text { S-transferase 1) }\end{array}$ & $283,006 \pm 56,731$ & $339,250 \pm 80,532$ & $208,100 \pm 117,469$ & $420,725 \pm 264,477$ & $294,994 \pm 229,390$ & NS \\
\hline $\begin{array}{c}\text { NFE2L2 } \\
\text { (nuclear factor erythroid } \\
\text { 2-related factor 2) }\end{array}$ & $238,775 \pm 89,756$ & $28,271 \pm 28,022$ & $143,538 \pm 78,523$ & $129,013 \pm 51,919$ & $127,938 \pm 25,088$ & 0.006 \\
\hline
\end{tabular}

The increased activity of the antioxidant enzymes suggests a restoration of the cell redox homeostasis, which had been disturbed by fluoride, and the highest tested magnetic induction had the strongest effect on cells.

\subsection{Transcriptional Activity of the Apoptosis-Related Genes}

The RT-qPCR analysis indicated statistically significant changes in the expression of the apoptosis-related genes such as CASP2, CASP9, TNF and TNFR1 among the tested cell groups (Table 2). The expression of CASP9 was significantly down regulated due to the action of the SMF with the $0.55 \mathrm{~T}$ (Tukey's post hoc test, $p=0.007$ ) and $0.65 \mathrm{~T}$ (Tukey's post hoc test, $p=0.017$ ) flux intensities compared to the fluoride-treated fibroblasts. In the case of the CASP2 expression, there was a statistically significant increase in the NaF-treated cells (Tukey's post hoc test, $p=0.003$ ) and in the cells that had been treated with fluoride and simultaneously exposed to the SMF with a $0.45 \mathrm{~T}$ flux density (Tukey's post hoc test, $p=0.008$ ) compared to the control cells. At the same time, the SMF with a $0.65 \mathrm{~T}$ flux density silenced its expression compared to the fluoride-treated cells (Tukey's post hoc test, $p=0.001$ ) and the cells that had been co-exposed to fluoride and the SMF with a $0.45 \mathrm{~T}$ flux density (Tukey's post hoc test, $p=0.003$ ). Similar relationships were observed for the TNF gene. There was a statistically significant increase in its expression in the NaF-treated cells (Tukey's post hoc test, $p=0.004$ ) and in the cells that had been treated with fluoride and simultaneously exposed to the SMF with a $0.45 \mathrm{~T}$ flux density (Tukey's post hoc test, $p=0.001$ ) compared to the control cells. Moreover, the SMFs with $0.55 \mathrm{~T}$ and $0.65 \mathrm{~T}$ flux densities silenced its expression compared to the fluoride-treated cells (Tukey's post hoc test, $p=0.009, p=0.038$, respectively) and simultaneously treated with fluoride and exposed to the SMF with $0.45 \mathrm{~T}$ flux density cells (Tukey's post hoc test, $p<0.001, p=0.011$, respectively). There was also a down regulation of TNF receptor 1 for the SMF with a $0.65 \mathrm{~T}$ flux density compared to the NaF-treated cells (Tukey's post hoc test, $p=0.043$ ). 
Table 2. The expression of the genes that are associated with the apoptosis process in fluoride-treated fibroblasts and in fibroblasts that had been treated with fluoride, and then subjected to the influence of SMFs of different intensities $(0.45,0.55$, and $0.65 \mathrm{~T})$ for $12 \mathrm{~h}$ compared to the control culture without fluoride and without the magnet (flux density $0.0 \mathrm{~T}$ ).

\begin{tabular}{|c|c|c|c|c|c|c|}
\hline & C & F & F + SMF1 & $F+S M F 2$ & $F+S M F 3$ & $* p$ \\
\hline \multicolumn{7}{|c|}{ mRNA Copy Numbers/ $\mu$ g RNA } \\
\hline $\begin{array}{c}B A X \\
\text { (BCL2 associated } \mathrm{X} \\
\text { apoptosis regulator) }\end{array}$ & $\begin{array}{c}162,150 \pm \\
56,390\end{array}$ & $\begin{array}{c}1,057,813 \pm \\
1,343,514\end{array}$ & $\begin{array}{c}260,906 \pm \\
90,299\end{array}$ & $\begin{array}{l}165,288 \pm \\
55,281\end{array}$ & $\begin{array}{c}315,338 \pm \\
278,153\end{array}$ & NS \\
\hline $\begin{array}{c}B C L 2 \\
\text { (B-cell lymphoma 2) }\end{array}$ & $\begin{array}{c}75,243 \pm \\
103,092\end{array}$ & $\begin{array}{l}56,350 \pm \\
9429\end{array}$ & $\begin{array}{c}62,225 \pm \\
34,664\end{array}$ & $\begin{array}{l}23,101 \pm \\
5323\end{array}$ & $\begin{array}{l}15,527 \pm \\
5319\end{array}$ & NS \\
\hline $\begin{array}{c}B C L X L \\
\text { (B-cell lymphoma- } \\
\text { extra large) }\end{array}$ & $\begin{array}{l}197,181 \pm \\
65,858\end{array}$ & $\begin{array}{c}271,883 \pm \\
47,827\end{array}$ & $\begin{array}{c}257,775 \pm \\
67,301\end{array}$ & $\begin{array}{l}158,491 \pm \\
42,901\end{array}$ & $\begin{array}{l}112,387 \pm \\
4472\end{array}$ & NS \\
\hline $\begin{array}{c}\text { FAS } \\
\text { (Fas cell surface death } \\
\text { receptor) }\end{array}$ & $\begin{array}{c}334,825 \pm \\
306,367\end{array}$ & $\begin{array}{c}1,068,306 \pm \\
1,029,560\end{array}$ & $\begin{array}{l}1,087,450 \pm \\
636,856\end{array}$ & $\begin{array}{l}439,381 \pm \\
298,303\end{array}$ & $\begin{array}{c}227,213 \pm \\
238,264\end{array}$ & NS \\
\hline $\begin{array}{c}F A S L \\
\text { (Fas ligand) }\end{array}$ & $356 \pm 421$ & $74 \pm 89$ & $149 \pm 85$ & $50 \pm 50$ & $51 \pm 27$ & NS \\
\hline $\begin{array}{c}\text { CASP9 } \\
\text { (caspase 9) }\end{array}$ & $\begin{array}{c}28,148 \pm \\
13,279\end{array}$ & $\begin{array}{l}37,381 \pm \\
5907\end{array}$ & $\begin{array}{c}31,013 \pm \\
8629\end{array}$ & $\begin{array}{c}14,529 \pm \\
4178\end{array}$ & $\begin{array}{l}16,955 \pm \\
2902\end{array}$ & 0.004 \\
\hline $\begin{array}{c}\text { CASP2 } \\
\text { (caspase 2) }\end{array}$ & $\begin{array}{l}116,188 \pm \\
30,287\end{array}$ & $\begin{array}{c}186,388 \pm \\
15,879\end{array}$ & $\begin{array}{c}178,963 \pm \\
14,011\end{array}$ & $\begin{array}{c}140,131 \pm \\
24,821\end{array}$ & $\begin{array}{c}108,763 \pm \\
21,211\end{array}$ & $<0.001$ \\
\hline $\begin{array}{c}\text { CASP3 } \\
\text { (caspase 3) }\end{array}$ & $\begin{array}{c}299,713 \pm \\
137,632\end{array}$ & $\begin{array}{l}480,000 \pm \\
94,438\end{array}$ & $\begin{array}{c}511,438 \pm \\
167,428\end{array}$ & $\begin{array}{c}283,938 \pm \\
43,039\end{array}$ & $\begin{array}{c}244,044 \pm \\
168,991\end{array}$ & NS \\
\hline $\begin{array}{c}\text { TNF } \\
\text { (tumor necrosis factor) }\end{array}$ & $\begin{array}{c}17,930 \pm \\
4651\end{array}$ & $\begin{array}{l}37,638 \pm \\
4096\end{array}$ & $\begin{array}{l}40,500 \pm \\
6992\end{array}$ & $\begin{array}{c}14,412 \pm \\
6424\end{array}$ & $\begin{array}{c}23,328 \pm \\
8232\end{array}$ & $<0.001$ \\
\hline $\begin{array}{c}\text { TNFR1 } \\
\text { (tumor necrosis factor } \\
\text { receptor } 1 \text { ) }\end{array}$ & $\begin{array}{c}6,600,625 \pm \\
4,298,333\end{array}$ & $\begin{array}{c}8,998,125 \pm \\
2,632,911\end{array}$ & $\begin{array}{c}8,421,875 \pm \\
1,566,133\end{array}$ & $\begin{array}{c}6,648,750 \pm \\
2,222,046\end{array}$ & $\begin{array}{c}3,122,875 \pm \\
1,240,915\end{array}$ & 0.049 \\
\hline
\end{tabular}

C-control cells; F-NaF-treated cells; F + SMF1-NaF-treated cells and exposed to SMF with $0.45 \mathrm{~T}$ flux density; F + SMF2-NaF-treated cells and exposed to SMF with $0.55 \mathrm{~T}$ flux density; F + SMF3-NaF-treated cells and exposed to SMF with $0.65 \mathrm{~T}$ flux density; the results are expressed as the means $\pm \mathrm{SD}$; statistical significance: ${ }^{*} p<0.05$, the one-way ANOVA test, NS-not statistically significant.

The above data indicate that the genes whose expression is associated with the induction of apoptosis are down regulated as a result of the exposure to a SMF; the effect was strongest on the cells that had been subjected to a SMF with a $0.65 \mathrm{~T}$ flux density.

\subsection{Apoptosis Assay}

A study of apoptosis using a flow cytometer showed that fluoride caused a reduction in the number of viable cells by $9.1 \%$. However, cell exposure to a SMF reduced fluoride-induced programmed cell death. This effect was stronger at the higher magnetic field intensities, i.e., the SMF with a $0.55 \mathrm{~T}$ flux density reduced the apoptosis process by $3.1 \%$ and the SMF with a $0.65 \mathrm{~T}$ flux density by 15.7\%. (Figure 1). 


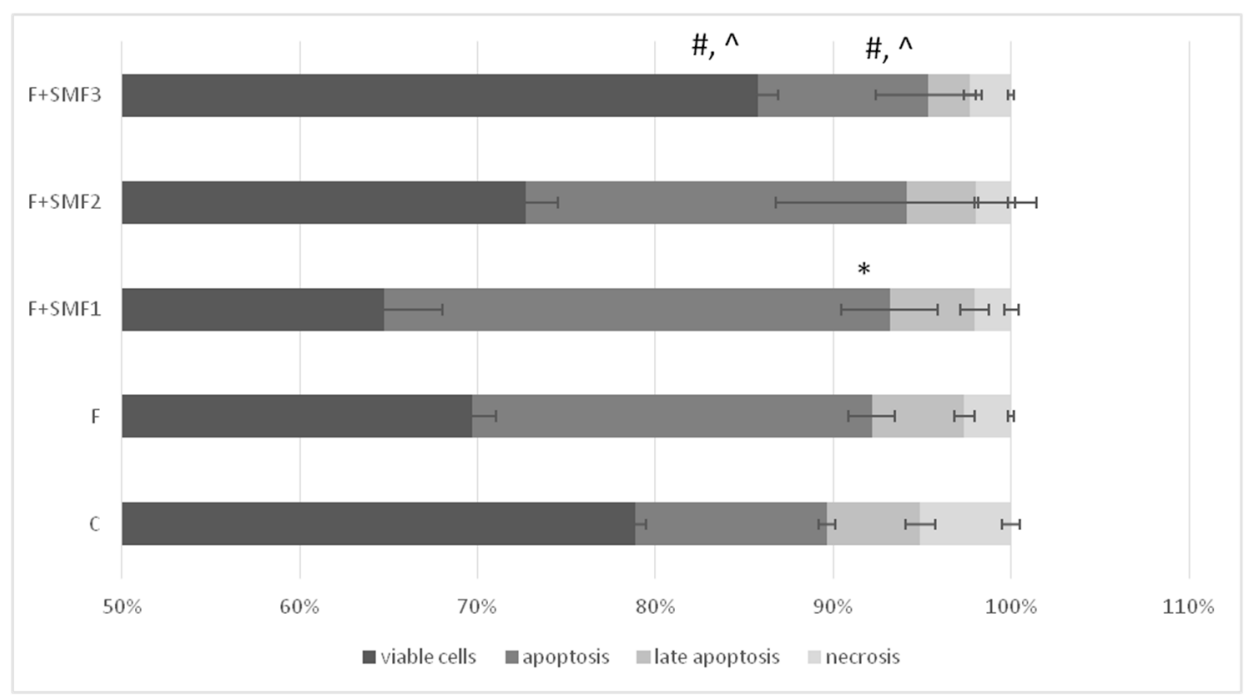

Figure 1. Apoptosis in fibroblasts co-exposed to fluoride and a SMF at a different magnetic induction for $12 \mathrm{~h}$ (C-control cells; F-NaF-treated cells; F + SMF1-NaF-treated cells exposed to SMF at a 0.45 T flux density; F + SMF2-NaF-treated cells exposed to SMF at a $0.55 \mathrm{~T}$ flux density; F + SMF3-NaF-treated cells exposed to SMF at a $0.65 \mathrm{~T}$ flux density). The results are expressed as the means $\pm \mathrm{SD}$, statistical significance: ${ }^{*} p<0.05$ vs. C; \# $p<0.05$ vs. F; ^ $p<0.05$ vs. F + SMF1).

\subsection{Relationships between Oxidative Stress and the Apoptosis Process}

In the next stage, a correlation analysis showed a strong relationship between apoptosis and the cellular antioxidant system. In the fibroblasts co-exposed to fluoride and a SMF, the correlations between the genes that are associated with apoptosis and the genes that are associated with the antioxidant system were negative, which indicates that a restoration of the redox balance is accompanied by an inhibition of the apoptosis process (Table 3).

Table 3. Pearson correlation of the gene expression associated with apoptosis and the cellular antioxidant status in NaF-treated fibroblasts and co-exposed to a SMF for $12 \mathrm{~h}$.

\begin{tabular}{ccccccccc}
\hline & SOD1 & SOD2 & GSR & NFE2L2 & CASP2 & CASP9 & TNF & TNFR1 \\
\hline SOD1 & & & & & & & & \\
\hline SOD2 & $\mathbf{0 . 7 2}$ & & & & & & & \\
\hline GSR & 0.41 & 0.45 & & & & & & \\
\hline NFE2L2 & 0.02 & -0.38 & -0.11 & & & & & \\
\hline CASP2 & -0.53 & -0.36 & $-\mathbf{0 . 7 1}$ & 0.29 & & & \\
\hline CASP9 & -0.33 & -0.08 & $\mathbf{- 0 . 6 2}$ & -0.29 & $\mathbf{0 . 6 9}$ & & \\
\hline TNF & 0.03 & -0.01 & -0.58 & -0.30 & 0.51 & $\mathbf{0 . 6 6}$ & & \\
\hline TNFR1 & -0.54 & -0.45 & $\mathbf{- 0 . 8 4}$ & 0.22 & $\mathbf{0 . 8 9}$ & $\mathbf{0 . 6 1}$ & 0.39 & \\
\hline
\end{tabular}

All values in bold are significant $p<0.05$.

In the next step, the relationships between the proteins encoded by the analysed genes were assessed using STRING analysis. The interaction network that was created (interaction score: high confidence -0.700) consisted of 17 nodes (proteins) and 47 edges (the expected number of edges was two). This showed that the predicted associations for an analysed group of proteins were statistically significant (enrichment $p<0.001$ ) and that these proteins, as a group, are connected biologically. Furthermore, this interaction network highlighted the fact that the protein that connects both processes, i.e., apoptosis and the cellular antioxidant system, is the Nrf2 transcription factor (NFE2L2) (Figure 2). 


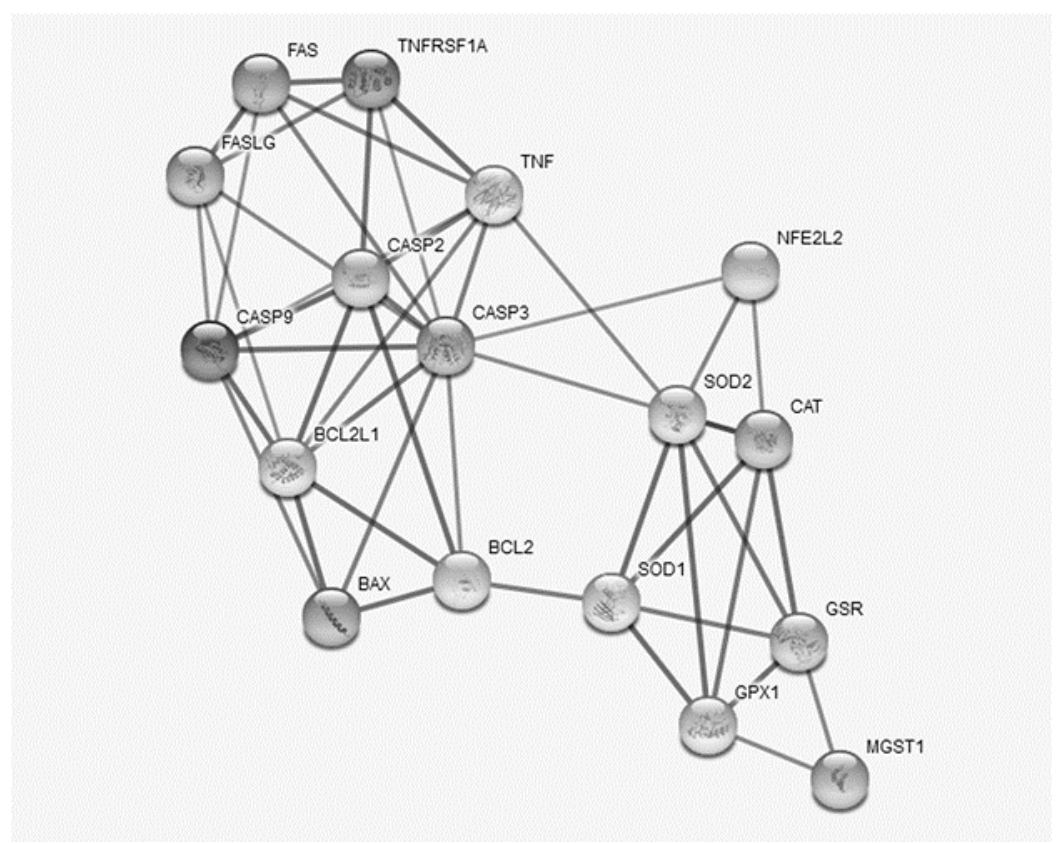

Figure 2. The protein interaction network created in a STRING database. The thickness of the line between the proteins indicates the degree of confidence prediction of the interaction.

\section{Discussion}

This work complements our previous works on the effects of fluoride on cell systems [11,12,23]. The toxicity of fluorine compounds has been proven and the results of the research have been widely described [24-26]. Among studies of a SMF as a neutralizer for the toxic effects of fluoride, in this study we focused on the process of apoptosis in correlation with oxidative stress and the NRF2 pathway. The process of apoptosis and the oxidative stress process are often discussed in the literature due to the number of diseases they cause [27-30].

It is known that free radicals induce apoptosis [27]. Although high levels of reactive oxygen species/reactive nitrogen species (ROS/RNS) are associated with apoptosis, the modulation of the activity of the transcription factors is triggered by low levels of free radicals [31].

There are extensive studies that show the influence of fluorine compounds on the apoptosis process and the oxidative system. In a study by Yan et al. [32], an increase in the production of ROS in microglia cells that had been treated with fluoride was proven. Additionally, Reddy et al. [33] proved the toxic effect of $\mathrm{NaF}$ on the vital functions of Wistar rats based on an analysis of the oxidative system. Moreover, in a study by $\mathrm{Lu}$ et al. [34], the effect of $\mathrm{NaF}$ on the process of apoptosis and oxidative stress in the livers of mice was demonstrated.

Despite numerous studies that confirm the toxic effect of fluoride, there are few studies that show the impact of SMFs in relation to fluorine compounds. Therefore, in our study we analysed the transcriptional activity of the genes that are related to the cellular oxidative system and the genes that are related to apoptosis in a fluoride-treated cell culture and SMF.

The analyses showed an increase in the expression of the SOD1, SOD2 and GSR genes in the culture that had been treated with a high-intensity SMF. Moreover, the analysis of the transcriptional activity of the selected genes that are related to apoptosis indicated a decrease in the expression of the genes that are involved in the induction of apoptosis under the influence of a SMF. This gives rise to the assumption that exposure to a SMF causes the normalization of apoptosis and redox homeostasis in cells that have been disturbed by fluoride. A SMF is another factor that may be involved in neutralizing the toxic effects of fluorine compounds [35]. 
The toxicity of fluorine compounds [36,37] was confirmed once again in the next stage of our own study on cell viability, which was assessed using the flow cytometer method. It was reaffirmed that exposure to a SMF reduced programmed cell death.

Fluoride is also known to inhibit Nrf2, which results in a reduction in the ability of cells to defend themselves against free radicals and oxidative stress [13]. In turn, a SMF activates the pathway that is associated with Nrf2 by increasing the expression of this gene, which strengthens the antioxidant defense of cells and increases the activity of the antioxidant enzymes.

In our study, we showed the relationship between the apoptotic process and the antioxidant system by linking them to Nrf2, which was confirmed by previous studies. Khan el al. [38] demonstrated that the inhibition of the activation of IL-1 $\beta$ induced external and internal apoptotic pathways as a result of the activation of Nrf2 in the OA chondrocytes. Other studies have also indicated a decrease in the rate of apoptosis after an increase in the expression of $\mathrm{Nrf} 2$ followed by a decrease in the activity of the caspases and an increase in the expression of Bcl-2/Bax, HO-1 [39]. However, Bonay et al. [40] showed that a caspase-independent and MAPK (mitogen-activated protein kinase)-dependent p38 cell apoptosis in mycobacteria infected macrophages was triggered by a stimulation of the Nfr2 signaling pathway, which was induced by sulforaphane.

Previously, we showed that the SMF can reduce oxidative stress and its effects [11]. In this study we indicated that a shorter exposure time to SMF also had this effect. This is important from the point of view of using it in therapy for redox imabalance diseases. As a result of the conducted analyses, it was proved that a SMF can act as a neutralizer for the toxic effects of fluorine compounds. The element that undoubtedly connects all of the stages of our research is the fact that the SMF with a flux density of $0.65 \mathrm{~T}$ was the one that had the strongest influence. We have shown that the stronger the magnetic induction, the better the effect, and that this effect is related to the NRF2 signaling pathway. The results of these studies can form the basis for developing therapeutic strategies for apoptosis and oxidative stress-related diseases.

Author Contributions: Conceptualization, M.K.-D. and A.K.; methodology, M.K.-D. and A.K.; formal analysis, M.K.-D. and A.S.-W.; investigation, M.K.-D. and A.S.-W.; writing-original draft preparation, M.K.-D. and A.K.; writing-review and editing, A.S.-W. All authors have read and agreed to the published version of the manuscript.

Funding: This study was supported by grant KNW-2-I10/N/9/N from the Medical University of Silesia, Katowice, Poland.

Conflicts of Interest: The authors declare no conflict of interest.

\section{References}

1. Wu, J.; Cheng, M.; Liu, Q.; Yang, J.; Wu, S.; Lu, X.; Jin, C.; Ma, H.; Cai, Y. Protective Role of tert-Butylhydroquinone Against Sodium Fluoride-Induced Oxidative Stress and Apoptosis in PC12 Cells. Cell Mol. Neurobiol. 2015, 35, 1017-1025. [CrossRef] [PubMed]

2. Yang, Y.; Huang, H.; Ba, Y.; Cheng, X.M.; Cui, L.X. Effect of oxidative stress on fluoride-induced apoptosis in primary cultured Sertoli cells of rats. Int. J. Environ. Health Res. 2015, 25, 1-9. [CrossRef] [PubMed]

3. Jakubczyk, K.; Dec, K.; Kałduńska, J.; Kawczuga, D.; Kochman, J.; Janda, K. Reactive oxygen species-Sources, functions, oxidative damage. Pol. Merkur Lekarski. 2020, 48, 124-127.

4. Tan, S.N.; Sim, S.P.; Khoo, A.S. Potential role of oxidative stress-induced apoptosis in mediating chromosomal rearrangements in nasopharyngeal carcinoma. Cell Biosci. 2016, 6, 35. [CrossRef]

5. Ozben, T. Oxidative stress and apoptosis: Impact on cancer therapy. J. Pharm. Sci. 2007, 96, 2181-2196. [CrossRef] [PubMed]

6. Ghodbane, S.; Lahbib, A.; Sakly, M.; Abdelmelek, H. Bioeffects of static magnetic fields: Oxidative stress, genotoxic effects, and cancer studies. Biomed. Res. Int. 2013, 2013, 602987. [CrossRef]

7. Kheifets, L.I.; Greenberg, R.S.; Neutra, R.R.; Hester, G.L.; Poole, C.L.; Rall, D.P.; Lundell, G. Electric and magnetic fields and cancer: Case study. Am. J. Epidemiol. 2001, 154, S50-S59. [CrossRef]

8. Albuquerque, W.W.; Costa, R.M.; de Fernandes, T.S.; Porto, A.L. Evidences of the static magnetic field influence on cellular systems. Prog. Biophys. Mol. Biol. 2016, 121, 16-28. [CrossRef] 
9. Coballase-Urrutia, E.; Navarro, L.; Ortiz, J.L.; Verdugo-Díaz, L.; Gallardo, J.M.; Hernández, M.E.; Estrada-Rojo, F. Static Magnetic Fields Modulate the Response of Different Oxidative Stress Markers in a Restraint Stress Model Animal. Biomed. Res. Int. 2018, 2018, 3960408. [CrossRef]

10. Sirmatel, O.; Sert, C.; Sirmatel, F.; Selek, S.; Yokus, B. Total antioxidant capacity, total oxidant status and oxidative stress index in the men exposed to 1.5 T static magnetic field. Gen. Physiol. Biophys. 2007, 26, 86-90.

11. Kimsa-Dudek, M.; Synowiec-Wojtarowicz, A.; Derewniuk, M.; Gawron, S.; Paul-Samojedny, M.; Kruszniewska-Rajs, C.; Pawłowska-Góral, K. Impact of fluoride and a static magnetic field on the gene expression that is associated with the antioxidant defense system of human fibroblasts. Chem. Biol. Interact. 2018, 287, 13-19. [CrossRef]

12. Kimsa-Dudek, M.; Synowiec-Wojtarowicz, A.; Derewniuk, M.; Paul-Samojedny, M.; Pawłowska-Góral, K. The effect of simultaneous exposure of human fibroblasts to fluoride and moderate intensity static magnetic fields. Int. J. Radiat. Biol. 2019, 95, 1581-1587. [CrossRef] [PubMed]

13. Verma, A.K.; Yadav, A.; Singh, S.V.; Mishra, P.; Rath, S.K. Isoniazid induces apoptosis: Role of oxidative stress and inhibition of nuclear translocation of nuclear factor (erythroid-derived 2)-like 2 (Nrf2). Life Sci. 2018, 199, 23-33. [CrossRef]

14. Yao, Y.; Wang, H.; Xu, F.; Zhang, Y.; Li, Z.; Ju, X.; Wang, L. Insoluble-bound polyphenols of adlay seed ameliorate H2O2-induced oxidative stress in HepG2 cells via Nrf2 signalling. Food Chem. 2020, 325, 126865. [CrossRef] [PubMed]

15. Ma, Q. Role of nrf2 in oxidative stress and toxicity. Annu. Rev. Pharmacol. Toxicol. 2013, 53, 401-426. [CrossRef] [PubMed]

16. Tu, W.; Wang, H.; Li, S.; Liu, Q.; Sha, H. The Anti-Inflammatory and Anti-Oxidant Mechanisms of the Keap1/Nrf2/ARE Signaling Pathway in Chronic Diseases. Aging Dis. 2019, 10, 637-651. [CrossRef]

17. Sun, P.; Nie, X.; Chen, X.; Yin, L.; Luo, J.; Sun, L.; Wan, C.; Jiang, S. Nrf2 Signaling Elicits a Neuroprotective Role Against PFOS-mediated Oxidative Damage and Apoptosis. Neurochem. Res. 2018, 43, 2446-2459. [CrossRef]

18. Zhang, W.; Li, M.; Li, N.; Liu, Z. Regulation of Keap-1/Nrf2 Signaling Pathway Is Activated by Oxidative Stress in Patients with Premature Rupture of Membranes. Med. Sci. Monit. 2020, 26, e921757. [CrossRef]

19. Gawron, S.; Glinka, M.; Wolnik, T. Magnetyczna komora badawcza dedykowana do hodowli komórek. Zeszyty Problemowe-Maszyny Elektryczne 2012, 4, 11-16.

20. Glinka, M.; Gawron, S.; Sieroń, A.; Pawłowska-Góral, K.; Cieślar, G.; Sieroń-Stołtny, K. Test chambers for cell culture in static magnetic field. J. Magn. Mater. 2013, 331, 208-215. [CrossRef]

21. Dini, L.; Abbro, L. Bioeffects of Moderate-Intensity Static Magnetic Fields on Cell Cultures. Micron 2005, 36, 195-217. [CrossRef] [PubMed]

22. Pawłowska-Góral, K.; Kimsa-Dudek, M.; Synowiec-Wojtarowicz, A.; Orchel, J.; Glinka, M.; Gawron, S. Effect of static magnetic fields and phloretin on antioxidant defense system of human fibroblasts. Environ. Sci. Pollut. Res. Int. 2016, 23, 14989-14996. [CrossRef] [PubMed]

23. Kimsa-Dudek, M.; Synowiec-Wojtarowicz, A.; Krawczyk, A.; Kruszniewska-Rajs, C.; Gawron, S.; Paul-Samojedny, M.; Gola, J. Anti-apoptotic effect of a static magnetic field in human cells that had been treated with sodium fluoride. J. Environ. Sci. Health A Tox. Hazard. Substain. Environ. Eng. 2020, 1-8. [CrossRef]

24. Dhar, V.; Bhatnagar, M. Physiology and toxity of fluoride. Indian J. Dent. Res. 2009, 20, 350-355. [CrossRef]

25. Whitford, G.M. Acute toxity of ingested fluride. Monogr. Oral Sci. 2011, 22, 66-80.

26. Wei, W.; Deng, H.; Cui, H.; Fang, J.; Zuo, Z.; Li, Y.; Wamg, X.; Zhao, L. A mini review of fluoride-induced apoptotic pathways. Environ. Sci. Pollut. Res. Int. 2018, 25, 33926-33935. [CrossRef]

27. Xu, X.; Lai, Y.; Hua, Z.C. Apoptosis and apoptotic body: Disease message and therapeutic target potentials. Biosci. Rep. 2019, 39, BSR20180992. [CrossRef]

28. Turkmen, K. Inflammation, oxidative stress, apoptosis, and autophagy in diabetes mellitus and diabetic kidney disease: The Four Horsemen of the Apocalypse. Int. Urol. Nephrol. 2017, 49, 837-844. [CrossRef]

29. Méndez-Armenta, M.; Nava-Ruiz, C.; Juárez-Rebollar, D.; Rodriguez-Martinez, E.; Gómez, P.Y. Oxidative stress associated with neuronal apoptosis in experimental models of epilepsy. Oxid. Med. Cell. Longev. 2014, 2014, 293689. [CrossRef] 
30. Hosseinzadeh, A.; Javad-Moosavi, S.A.; Reiter, R.J.; Yarahmadi, R.; Ghaznavi, H.; Mehrzadi, S. Oxidative/nitrosative stress, autophagy and apoptosis as therapeutic targets of melatonin in idiopathic pulmonary fibrosis. Expert Opin. Ther. Targets 2018, 22, 1049-1061. [CrossRef]

31. Blomgren, K.; Hagberg, H. Free radicals, mitochondria, and hypoxia-ischemia in the developing brain. Free Radic. Biol. Med. 2006, 40, 388-397. [CrossRef] [PubMed]

32. Yan, L.; Liu, S.; Wang, C.; Wang, F.; Song, Y.; Yan, N.; Xi, S.; Liu, Z.; Sun, G. JNK and NADPH oxidase involved in fluoride-induced oxidative stress in BV-2 microglia cells. Mediators Inflamm. 2013, 2013, 895975. [CrossRef] [PubMed]

33. Reddy, Y.P.; Tiwari, S.K.; Shaik, A.P.; Alsaeed, A.; Sultana, A.; Reddy, P.K. Effect of sodium fluoride on neuroimmunological parameters, oxidative stress and antioxidative defenses. Toxicol. Mech. Methods 2014, 24, 31-36. [CrossRef] [PubMed]

34. Lu, Y.; Luo, Q.; Cui, H.; Deng, H.; Kuang, P.; Liu, H.; Fang, J.; Zuo, Z.; Deng, J.; Li, Y.; et al. Sodium fluoride causes oxidative stress and apoptosis in the mouse liver. Aging 2017, 9, 1623-1639. [CrossRef]

35. Ameeramja, J.; Perumal, E. Possible Modulatory Effect of Tamarind Seed Coat Extract on Fluoride-Induced Pulmonary Inflammation and Fibrosis in Rats. Inflammation 2018, 41, 886-895. [CrossRef]

36. Zuo, H.; Chen, L.; Kong, M.; Qiu, L.; Lü, P.; Wu, P.; Yang, Y.; Chen, K. Toxic effects of fluoride on organisms. Life Sci. 2018, 198, 18-24. [CrossRef]

37. Grandjean, P. Developmental fluoride neurotoxicity: An updated review. Environ. Health 2019, 18, 110. [CrossRef]

38. Khan, N.M.; Ahmad, I.; Haqqi, T.M. Nrf2/ARE pathway attenuates oxidative and apoptotic response in human osteoarthritis chondrocytes by activating ERK1/2/ELK1-P70S6K-P90RSK signaling axis. Free Radic. Biol. Med. 2018, 116, 159-171. [CrossRef]

39. Pan, H.; Wang, H.; Zhu, L.; Wang, X.; Cong, Z.; Sun, K.; Fan, Y. The involvement of Nrf2-ARE pathway in regulation of apoptosis in human glioblastoma cell U251. Neurol. Res. 2013, 35, 71-78. [CrossRef]

40. Bonay, M.; Deramaudt, T.B. Nrf2: New insight in cell apoptosis. Cell Death Dis. 2015, 6, e1897. [CrossRef]

(C) 2020 by the authors. Licensee MDPI, Basel, Switzerland. This article is an open access article distributed under the terms and conditions of the Creative Commons Attribution (CC BY) license (http://creativecommons.org/licenses/by/4.0/). 